\title{
Pilgrimage to Hajj: An Information Journey
}

\author{
Nadia Caidi, University of Toronto, Canada
}

\begin{abstract}
Completing a pilgrimage has often been touted as a transformational experience. Yet, pilgrimage as an information context is sorely lacking in our field, despite the valuable insights it could provide into the complex information environments and evolving states of those who undertake pilgrimage. In this article, I examine a specific pilgrimage: the Hajj in Mecca (Saudi Arabia). Preparing for Hajj involves a series of stages encompassing material, spiritual, and informational dimensions. Using a qualitative and exploratory approach, this study applies the lens of pilgrimage as 'lived religion' and makes explicit the detailed activities and outcomes of pilgrim information practices, and the ways in which information in its multiple forms (textual, spiritual, corporeal, etc.) has mediated and shaped the pilgrims' journey. I build on established theories in information behavior and meaning-making in the context of everyday life, as well as the literature on pilgrimage and pilgrimage as 'lived religion' to relate the participants' encounter with Hajj and their experiences toward becoming a Hajji/-a (someone who has completed the Hajj). Findings based on interviews with twelve (12) global Hajj goers suggest that pilgrims' information practices are varied, and transcend both individual (cognitive, affective) as well as social processes (through shared imaginaries and a translocal network of people and resources). The study illustrates the importance of examining diverse transformational experiences in LIS, and the rich contributions that our field can make to these research contexts.
\end{abstract}

Keywords: information practices; Islam; meaning making; pilgrimage; religion

Publication Type: research article

\section{Introduction}

$\mathrm{R}$ eligious and secular pilgrimages have a long history and continue to hold a prominent place in many people's lives today. There are many different types of pilgrimages, from the religious to the spiritual to the secular, and while they fulfill different purposes, they all have in common this quest for a transformational experience. There exists a rich body of scholarship on pilgrimage from such disciplines as religious studies, anthropology, art, history, architecture, and tourism (Badone \& Roseman, 2004; Coleman \& Elsner, 1995; Eade \& Sallnow, 1991; Elsner \& Rutherford, 2005; Janin, 2002; Lloyd, 1998; Norman \& Cusack, 2015; Post \& van der Beek, 2016; Ross-Bryant, 2017; Turner, 1969; van Gennep, 1960), among others. Yet, pilgrimage as a context of research in information studies has been surprisingly overlooked (exceptions include Bati, 2015; Caidi, Beazley, \& Colomer Marquez, 2018, along with some foundational work on religious and/or spiritual experiences by Gaston, Dorner, \& Johnstone, 2015; Gorichanaz, 2016; Guzik, 2013; Kari, 2007; Roland \& Wicks, 2010). This article contributes to this line of research by offering an information perspective to the study of pilgrimage, shedding light on approaches and concepts from our field that can enrich our understanding of the complexities of the pilgrim's journey through the lens of information practices, identity construction, meaning-making, and community-building in a global and digital world.

The International Journal of Information, Diversity, \& Inclusion, 3(1), 2019

ISSN 2574-3430, https://jps. library.utoronto.ca/index.php/ijidi 
In this article, I adapt Allard and Caidi's (2018) translocal meaning making (TMM) model, which builds on Appadurai's (1996) work on social imaginaries and the notion of translocality in order to interrogate how meaning-making occurs in the context of information experience during spiritual/religious journeys of global pilgrims. Methodologically, this study highlights the value of closely examining pilgrimage stories to gain a deep appreciation for how pilgrims encounter and make sense of Hajj landscape, and transition toward a collectively shared construction of what it means to become a Hajji/Hajja (one who has completed Hajj and returns a changed person whose social status has been altered), as well as the intricate dynamics of religious/spiritual experiences. In-depth semi-structured interviews were conducted with 12 pilgrims to the holy sites in and around Mecca (Saudi Arabia). The findings articulate the processes of negotiating meaning and evaluating information resources in shifting and unknown contexts. This study should be of interest to information scholars and practitioners eager to have a better grasp of the dynamics-and the information practices-associated with transformational experiences (i.e., spiritual and/or contemplative aspects of human existence), as these are found in every culture. Information and memory institutions (libraries, archives, museums, art galleries) are potentially ideal sites for the sharing of transformational experiences and for facilitating transcultural affinities as part of their mission to increase diversity and inclusion. The findings should also be of interest to pilgrimage scholars as the study applies an information lens to the experiences of pilgrims by examining both their information and media practices as well as how these mediate their learning and meaning-making when navigating complex translocal contexts.

It must be noted that I examine a particular type of pilgrimage here: Hajj is one of the world's largest religious gatherings; in 2017, approximately 1.8 million pilgrims visited Mecca to complete Hajj, while another 19 million Muslims completed the Umrah-often referred to as the "small" or "lesser" pilgrimage to Mecca' (Kingdom of Saudi Arabia, General Statistics Authority, 2018). Hajj is performed at a specified time every year, during the twelfth month of the Muslim lunar calendar. During Hajj, millions of Muslim men and women congregate in Mecca to carry out specified rituals at a series of locations, with the aim of absolving themselves of sins. Completing Hajj is one of the five foundational pillars of Islam, an obligation all Muslim men and women of sufficient ability and means must fulfill at least once in their lifetime. It also corresponds to a profound and unifying set of rituals performed in the Muslim world (Clingingsmith, Khwaja, \& Kremer, 2009, p. 1134), as well as an embodiment of the transhistorical and transnational Muslim community (Ummah). Despite it being a pivotal, transformational moment in the social and religious life of the pilgrim, there is a dearth of research on the information aspects of Hajj, or any other pilgrimage for that matter. Moreover, we know from pilgrimage researchers that, after they return home, pilgrims tend to remain deeply affected by that experience in the context of their everyday life and practices (Frey, 2004; van der Beek, 2014, 2017).

\section{Literature Review}

It is fair to say that religion as a diversity characteristic, and religious/spiritual experiences as contexts for information research, are few and far between. In the field of information science, few scholars have examined the information environments of individuals in the context of their religious or spiritual practices. Some notable studies include Kari's (2007) review of the spiritual in information studies, along with studies about the information behavior of clergy members (Lambert, 2010; Michels, 2012; Roland, 2012; Wicks, 1999) or the nature of information in profound and transcendental experiences (Gorichanaz, 2016; Kari \& Hartel, 2007). Outside the Western religious traditions, there seems to be even less attention being paid to the intersection

The International Journal of Information, Diversity, \& Inclusion, 3(1), 2019

ISSN 2574-3430, https://jps.library.utoronto.ca/index.php/ijidi 
of information and religious/spiritual experiences, with a few exceptions such as Caidi et al. (2018) on selfie-taking practices during Hajj, Gaston et al. (2015) on Buddhism and sense-making, or Guzik (2013) on converts to Islam.

It is worth noting that outside the information studies field, there is a huge interest in the massive entertainment and consumer industry created around religious practices and holidays (Carneiro, Eusébio, \& Santos, 2016; Essoo \& Dibb, 2004; Freeman \& Bell, 2013; Minton, 2018). Similarly, the rise in religious or spiritual travels in the 20th century has been linked in part to the ease and convenience of travel and in part to the phenomena of memory work and affiliative identities by diasporic communities, often taking key (pilgrimage) sites as focal points (Caidi et al., 2018; Innocenti, 2015, 2016; Liebelt, Shenar, \& Werber, 2010). An in-depth review of pilgrimage scholarship is beyond the scope of this article; however, it is worth mentioning that, for a long time, pilgrimage scholarship centered around the unifying role of rituals in religion. Examples include van Gennep's model (1960) of the stages of separation, transition, and incorporation and Turner's 1969 work on communion (which he called "communitas") as experienced by pilgrims during the transitional, liminal phase. Turner's influential model, which shaped the anthropological study of pilgrimage for more than two decades, started to be questioned in the late 1980s, particularly its emphasis on a static, bounded ritual whose performance was isolated from everyday life. Pilgrimage scholars noted the historical and cultural embeddedness of pilgrimages (Coleman, 2002; Eade \& Sallnow, 2000; Sallnow, 1981). Pilgrimage sites, according to Eade and Sallnow (1991), were best understood as "empty vessels" reflecting competing religious and secular discourses of pilgrims. By emphasizing "motion" (Coleman \& Eade, 2004, p. 3 ) or mobility (Frey, 2004) as key aspects of sacred pilgrimages, pilgrimage scholars unhooked pilgrimage from its confinement to a holy place and conceptualized it instead as a ritual dynamic space. The door was open for considering pilgrimage's embeddedness into everyday life (Badone \& Roseman, 2004; Edensor, 1998).

Apprehending pilgrimage as part of everyday "lived religion" (Buitelaar, 2015) paves the way for a more holistic approach that encompasses social phenomenology, everyday information practices (Savolainen, 1995, 2008), and techno-spiritual practices (Bell, 2006). Scholars such as Flaskerud and Natvig (2018) exhort us to think about "what pilgrims take from heritage, materially as well as conceptually and emotionally, and how this process affects the pilgrims' life at home and their home community" (p. 2). Buitelaar (2015), in turn, examines religiosity through the lens of social identification and self-identity (p. 17). As can be seen, a common theme between these bodies of research is the notion that pilgrimage implies a state of flux and transition, along with an associated set of situated practices.

I build on this body of literature to examine pilgrims' information practices and meaning-making in the context of their once-in-a-lifetime journey. To accomplish this task, I draw from disparate literature, connecting pilgrimage scholarship to Appadurai (1996)'s social imaginaries as well as to work on translocality (Brickell \& Datta, 2011). Translocality, in the context of this study, refers to the multi-sited sociocultural and geographical spaces that pilgrims navigate as part of Hajj. They rely on, and are imbricated in, a multitude of spaces and networks (local and transnational), using these networks for preparing for Hajj (seeking information), performing Hajj (applying their knowledge and gaining new knowledge), and returning home as a Hajji/-a (sharing information, stories, emotions).

In keeping with Allard and Caidi (2018), I also use Appadurai's concept of "social imaginaries" to this examination of Hajj. Social imaginaries refer to "imagined worlds of places never visited before but socially constructed and imagined through the connections enabled and amplified by

The International Journal of Information, Diversity, \& Inclusion, 3(1), 2019 ISSN 2574-3430, https://jps.library.utoronto.ca/index.php/ijidi 
information and communication technologies" and that "frequently transcends national space" (Appadurai, 1996, p. 6). Locating Appadurai's notion of social imaginaries about Hajj alongside translocality, I seek to demonstrate evidence of the deeply affective imaginaries that connect people and places across borders, as well as their enactment through situated information practices. To account for these situated practices, I build on the five-step process of translocal meaning making (TMM) elaborated by Allard and Caidi (2018) and Allard (2015). The TMM model was initially devised to identify and map the migration stages through which Filipino migrants moved as they prepared to migrate and settle in Winnipeg, Canada; and subsequently located participants' information practices within these migration stages (Allard, 2015). Summarizing these findings and locating them within a broader transnational and social context, a process of TMM emerges that demonstrates how participants' meaning-making processes shift across both time and space and are deeply embedded within participants' translocal social spheres. Given the global nature of Hajj, the TMM model seems like an appropriate framework to examine how Hajj pilgrims make sense of their journey toward Mecca and the diversity and situatedness of their practices while there and upon their return home.

\section{Methods}

This study examines the nature of information in the lives of 12 Hajj pilgrims. It is part of a broader study that sought to examine the expression of spiritual and/or religious identities by young Muslims (aged 18-35), along with their media and technology practices at Hajj (see Caidi et al., 2018). Hajj has been traditionally viewed as something that one completes later in life (i.e., more sins to cleanse at that point) and also because Hajj is a costly endeavor. We see, however, the number of young people who have completed Hajj increasing, thus raising questions about the meaning of Hajj for young people and how Hajj is experienced by young Muslims in today's global and networked environment.

The research, both qualitative and exploratory, consists of 12 in-depth semi-structured interviews conducted between July 2014 and October 2017. ${ }^{2}$ Beyond assessing how the participants (all of whom completed Hajj) found, used, and shared information as they prepared for, undertook, and returned from Hajj, attention was also paid to how these pilgrims' practices across time and space contributed to their meaning making as part of their pilgrimage journey. Participants were selected on the basis of having completed Hajj within five years of the date of interview. Participants were recruited through public postings, via personal networks, and through word of mouth. In one case, a spouse was interviewed, providing a particularly rich description of family pilgrimage experiences. Participants were mostly located in Canada $(\mathrm{N}=8)$, but through videoconferencing (using Skype), other participants were contacted in France $(\mathrm{N}=2)$, the United States $(\mathrm{N}=1)$, and Bangladesh $(\mathrm{N}=1)$. Interviews were conducted in English (and French, in two cases), audio recorded, and lasted on average two hours. It is worth noting that the process of recruiting 12 participants took longer than anticipated and may have had to do with the age range selected (young adults aged 18-35). By the same token, the fact that one had completed Hajj at this point in one's life may indicate something about one's status (i.e., a devout, practicing, and financially able Muslim), which could have triggered reluctance and/or suspicion about participation in a study that targets young Muslims specifically (especially in a post-9/11 world). Word of mouth and active involvement and explanation of the purpose of the study (along with help from several student assistants, some of whom were members of the Muslim community) were essential in meeting the target goals. The focus on younger adults (1835) was motivated by an interest in examining an understudied segment of Hajj pilgrims, as well as contemporary expressions of young people's spiritual/religious identities.

The International Journal of Information, Diversity, \& Inclusion, 3(1), 2019

ISSN 2574-3430, https://jps.library.utoronto.ca/index.php/ijidi 
The interviews were designed to capture participants' trajectories following their decision to undertake the pilgrimage to Mecca. Broadly speaking, interview questions were designed to elicit participants' transnational and transitional experiences of completing Hajj (and associated information practices) before departure, during their time in Saudi Arabia, and upon their return from Hajj. To mitigate decay in memory, follow-up emails allowed participants to reflect on, remember, or add to the accounts of their experiences. The interview format of each interview began with broad questions about participants' feelings and experiences about Hajj. Participants were also asked to identify and evaluate all the information resources they used based on the accounts of their Hajj experiences. Moving through the interview in this fashion prompted recall; it also prompted participants to embed their information practices and experiences within their often very thoughtful and reflexive descriptions of their pilgrimage experiences. (See full interview guide in Appendix.)

The first phase of analysis started during data collection, as the interviewer attempted to understand the experience from the participants' perspective. A close reading of the transcriptions aimed at discerning any qualitative variation between the different experiences of the phenomenon by participants. During analysis, the focus shifted from individuals' experiences to a focus on collective experience. All interviews were coded and analyzed using line-by-line inductive analysis (Corbin \& Strauss, 2007). Using this iterative data-driven approach, the study identified several themes that address the relationship between participants' accounts and experiences of their Hajj experiences and their related and shifting information practices over time. Themes include: the importance to would-be pilgrims of broad and globally circulating narratives about Hajj as a "once-in-a-lifetime journey"; the intense and mixed feelings (emotion, anxiety, exhilaration, quest for authenticity) that follow the niyya (a mandatory requirement to make the intention of completing Hajj, without which Hajj is not considered "valid"); the recounting of and reflection upon a series of shifting information activities (including the role of Hajj tour operators and a marked ambivalence toward using online resources) that became more sophisticated over time; and finally, self-reflection on participants' own understanding of both their (often transformational) Hajj experience and the pilgrim's negotiation of the return home.

\section{Participant Profiles}

Twelve participants (P1-P12) in this study were aged between 18 and 35 and included five men and seven women. Participants were mostly married middle-class professionals, some with young families, and were typically well-educated and proficient in either English or French (the two languages in which the interviews were conducted). It is worth noting the participants' fluency in several languages (Urdu, French, Arabic, Pashto, and Bengali, among others). Most of the participants had completed one Hajj, and a few participants had performed another pilgrimage (two did Umrah, and another had performed two Hajj and two Umrah pilgrimages in total). (See Table 1.)

It must be noted that completing Hajj (outside of Saudi Arabia) requires that participants apply for a Hajj visa at their place of residence. ${ }^{3}$ A would-be pilgrim cannot simply show up in Saudi Arabia for the pilgrimage. Instead, he/she needs to secure the services of Saudi-certified Hajj travel operators who are responsible for the logistics (arranging transportation, lodging, visas, assistance regarding the rituals, etc.). In addition, women have to be accompanied by a male spouse or a male family member (this restriction has been loosened for women over 60 years of age). As this article will demonstrate, these requirements shaped participants' information practices, especially the timing of their pilgrimage, and their reliance on specific sources.

The International Journal of Information, Diversity, \& Inclusion, 3(1), 2019

ISSN 2574-3430, https://jps.library.utoronto.ca/index.php/ijidi 
Table 1. Participants' demographic characteristics

\begin{tabular}{|c|c|c|c|c|c|c|c|}
\hline Gender & $\begin{array}{l}\text { Age } \\
\text { Range }\end{array}$ & Ethnicity & $\begin{array}{l}\text { Pilgrimage, } \\
\text { Year }\end{array}$ & Status & $\begin{array}{l}\text { Country of } \\
\text { Residence }\end{array}$ & Occupation & $\begin{array}{l}\text { Languages } \\
\text { Fluency }\end{array}$ \\
\hline $\mathrm{F}$ & $30-35$ & $\begin{array}{l}\text { South } \\
\text { Asian }\end{array}$ & Hajj, 2012 & Married & Canada & Employed & English/Urdu \\
\hline M & $30-35$ & $\begin{array}{l}\text { South } \\
\text { Asian }\end{array}$ & Hajj, 2012 & Married & Canada & Employed & English/Urdu \\
\hline M & $30-35$ & $\begin{array}{l}\text { Middle } \\
\text { Eastern }\end{array}$ & Hajj, 2010 & Married & Canada & Self-Employed & English/Arabic \\
\hline $\mathrm{F}$ & $18-24$ & $\begin{array}{l}\text { Central } \\
\text { Asian }\end{array}$ & Hajj, 2013 & Single & Canada & Employed & English/Pashto \\
\hline M & $25-29$ & $\begin{array}{l}\text { South } \\
\text { Asian }\end{array}$ & $\begin{array}{l}\text { Umrah, 2005, } \\
\text { Hajj, } 2006\end{array}$ & Married & Canada & Student & English/Bengali \\
\hline $\mathrm{F}$ & $25-29$ & $\begin{array}{l}\text { South } \\
\text { Asian }\end{array}$ & Hajj, 2012 & Married & Canada & Unemployed & English/Urdu \\
\hline $\mathrm{F}$ & $25-29$ & $\begin{array}{l}\text { South East } \\
\text { Asian }\end{array}$ & Hajj, 2013 & Married & Canada & Employed & English/Bahasa \\
\hline $\mathrm{F}$ & $30-35$ & $\begin{array}{l}\text { South } \\
\text { Asian }\end{array}$ & $\begin{array}{l}\text { Hajj (x2), } \\
\text { Umrah, } 2014\end{array}$ & Single & USA & Student & English/Urdu \\
\hline M & $25-29$ & $\begin{array}{l}\text { North } \\
\text { African }\end{array}$ & Hajj, 2010 & Married & France & Employed & French/Arabic \\
\hline $\mathrm{F}$ & $25-29$ & $\begin{array}{l}\text { North } \\
\text { African }\end{array}$ & $\begin{array}{l}\text { Hajj, 2011, } \\
\text { Umrah, } 2010\end{array}$ & Single & France & Employed & $\begin{array}{l}\text { French/Arabic/ } \\
\text { Berber }\end{array}$ \\
\hline $\mathrm{F}$ & $25-29$ & $\begin{array}{l}\text { South } \\
\text { Asian }\end{array}$ & Hajj, 2014 & Married & Canada & Employed & English/Gujarati \\
\hline M & $30-35$ & $\begin{array}{l}\text { South } \\
\text { Asian }\end{array}$ & Hajj, 2017 & Married & Bangladesh & Employed & Bengali/English \\
\hline
\end{tabular}

\section{Findings}

Drawing from interview data with participants, this article identifies the varied ways in which participants engage with information resources as they prepare to leave for Hajj, complete the 
rituals, and return home. The stages of the TMM process elaborated by Allard (2015) and Allard and Caidi (2018) were adapted to explore the meaning-making that is an important and dynamic aspect of information work (Savolainen, 2016). The findings from this study demonstrate how participants work to navigate and come to understand novel information contexts, drawing from (sometimes conflicting) transnationally located information, narratives, and resources about Hajj.

\section{Step 1: Imagining Mecca and the Holy Sites}

Much like in Allard and Caidi's (2018) study, the first step in the TMM process takes place in the home country as would-be pilgrims actively imagine their journey. In the case of the 12 participants, they expressed varied expectations about what their Hajj pilgrimage would entail. In all cases, however, the process of imagining Mecca occurs within nostalgic childhood stories and imagery, especially the representations of the Kaaba, omnipresent in most Muslim homes. Located inside the Holy Mosque in Mecca, the Kaaba is a cube-shaped structure that pilgrims circumambulate around during the pilgrimage ritual. (It is also known as the House of Allah and is the direction toward which Muslims all over the world turn for the five daily prayers). Its symbolic power is therefore tremendous, and Hajj memories of participants are often related to images of the Kaaba. Participants also recount the memories of loved ones and relatives who had performed Hajj. Often their memories are tied to celebrations and gift-giving by pilgrims who brought back Zamzam water (from a sacred well in the holy sites), boxes of dates, prayer mats or beads, incense, and other token items from the holy sites. These narratives, what Appadurai (1996) calls social imaginaries, deeply impacted participants' expectations about journeying to Mecca.

Completing Hajj is also considered a blessing and a symbolic statement in global diasporic Muslim networks: returning home as a Hajji/-a confers you a special social status in Muslim societies, positioning you as a devout and (presumably) wiser person. It also denotes that you are able (physically and financially) to fulfill a key religious obligation. It must be noted that Hajj was a pilgrimage that traditionally tended to be done toward the end of one's life, because the journey to Hajj was considered both perilous and costly. However, the ease of access and convenience of modern travels puts Mecca all but a long-distance flight away. Consequently, changes in the demographics of pilgrims are taking place, with an increase in younger people completing the pilgrimage.

Pilgrims' imaginaries were generated from stories and information they received from their social network ties locally and abroad. Participants both actively sought and passively encountered information about Hajj through a variety of means. P4 recounts stories about Hajj learned in childhood: "Hajj is well known to any Muslim person: this place called Mecca, this journey called Hajj, this structure called Kaaba, the story of how it was built." P8 concurs, recalling her experiences:

I remember my grandparents preparing to go, in Pakistan. It took them a lot of planning. It was a big deal. The whole family came together to help them prepare. When my parents went, I was 16 . It is something that I always knew about and wanted to do, but later in life. All I knew were things I heard, and pictures I had seen. Back then, there was no live streaming, only stories. (P8)

What stood out for P5 as Hajj memories were "pictures of people wearing the same piece of clothing. They all looked the same. That's the image I remember from Hajj." P9 narrates that 
Hajj was always associated in his mind "with old age, and the idea that before one dies one ought to go. It is cultural too. In the Maghreb [North Africa], people go to Hajj much later in life." P3 concurs: "We heard stories of people and hardship, like the old man who didn't make it back. It is the journey of 'you don't know the answer of the return.'”

Social media browsing of friends' sites who did the pilgrimage and conversations with others locally and abroad about Hajj also prompted participants to imagine the holy sites, and to envision how they would feel being in that place. Participants' social networks are especially instrumental in promoting a social imaginary about Hajj. Contact and connections with other Hajjis living locally or abroad allow would-be pilgrims to assemble very particular imaginaries and expectations about their own Hajj experiences:

I didn't know what to expect also. It is such an incredible experience. My friends had told me about the sensory overload, the smells, etc. But even if people tell you these things, you couldn't really believe or truly take it in until you experience that yourself. (P5)

I wanted to hear the experience of others who had gone before me. Especially the elder ones. They had known the Kaaba the way it used to be. Without all the materialism that we see now, the fast foods and the malls. (P9)

I was mentally ready. I prepared myself. I heard stories from people about how to manage things. Some had done it recently, but others did it maybe 4-5 years ago. These other pilgrims gave me information: they told me about Maqam Ibrahim and Hijr Aswad. They told me not to go to particular places: it is too hard to stand there, too many people and you can get hurt. Don't go to rush areas also. When you go to Arafat, be very careful when you go to collect pebbles. (P6)

While Hajj is a rallying and unifying experience for pilgrims from all parts of the Muslim world, our findings also point to the rich and varied experiences as recounted by the 12 participants. Each story was unique in many ways, shedding light on the myriad ways our participants experienced what they all referred to as a life-altering journey, one that can only be truly comprehended by experiencing it. This journey almost always starts with "the calling," that moment when an individual consciously makes the decision to complete Hajj, which is then formalized into the niyya (or proclaimed intention to perform Hajj, which is an obligation upon the pilgrim). When asked about "the calling" or trigger that they associated with their decision to perform Hajj, a range of reasons were provided. For P1, it was soon after she got married that she and her husband decided to complete Hajj. She recounts:

After I got married, I told my husband I wanted to do Hajj. My husband was on board too. We made the intention, before January. It was like our New Year resolution. We paid the deposit with Hajj tour operator. The decision to go to Hajj also coincided with planning our family life. We decided to do Hajj first, and then tackle these other goals after that. We made it a priority.

P2 and his wife also jointly decided to complete Hajj. He refers to a Hadith (a religious edict attributed to the Prophet Muhammad) to explain what triggered his decision to complete Hajj. P2 states: "There are serious warnings about delaying Hajj while having the means and the provisions to perform it. I had property that I had inherited at the time so I was eligible to do so." P3 expressed a similar interest in fulfilling this religious obligation, which he articulates as 
follows: "My wife and I saved up money. We had the means, and the obligation was there," before adding, "My wife more so than me wanted to do it, because we had been married for a long time but had no children. We tried but were not having children. It wasn't in God's plan." P3 mentions that the couple became pregnant the year following their Hajj. P3's wife, who was also a participant, refers to this episode by stating:

Hajj is where my life changed. I got pregnant one month after we returned from Hajj. So we were so blessed. Our child was our gift. I made lots of du'as [invocations] during Hajj to have a child. I asked everyone who went with me to pray for me to have a child. So every time I see her, I am reminded. I want to take her there inshallah [God willing] one day. (P6)

P4 was the youngest participant. She completed Hajj with her parents when she was only 17 . She explains her situation in no minced terms:

I was not given an option. That decision was made for me. I felt a sense of loss of control over my life. This is a personal and spiritual journey. How could my parents make that decision for me? It is between me and Allah. It is about my rewards and sins. Maybe I wasn't ready to change my life and who I was. ... I don't regret it. I just wish they had asked me.

P5 refers to his Hajj as an "unorthodox pilgrimage." While in Saudi Arabia to perform Umrah, he decided to overextend his stay and complete Hajj. Not having the required paperwork and authorizations, P5's Hajj experience was quite unusual: “I ended up hiring a cab driver and crossing at another place away from the official checkpoints. I was young, I wouldn't do it like this now. All I had was a backpack." His Hajj was less organized than that of the others, and he relied mostly on his local friends for information and advice about logistical matters. His trigger to accomplish Hajj was the sense of communion with fellow Muslims that he experienced during Umrah. "As Muslims in the West, we sometimes feel disconnected from other Muslims and when I was standing there, I felt very connected at that point. Scores of people as far as the eye can see. That image stayed with me."

P7 describes Hajj as "a great way to start my life with my husband" and experience something spiritual with him before they started a family. As for P8, she recalls the intense feelings she experienced after she dropped her parents off at the airport (they were heading to Hajj):

I dropped them off at the airport and I was crying and I was being comforted. I cried because I wanted to go with them. I wanted to be going. My heart knew it needed to be there too. Eventually I did go. ... Ever since I went, I wanted to go back. It is the only place in the world where I felt at peace. ... I always had this pull to go there.

As can be seen, the participants' contexts and their decisions to go for Hajj vary from one situation to the other. At times, Hajj as an obligation is mentioned. Elsewhere the decision is based on one's readiness, stage in life, family situation, priorities, spiritual state, financial ability, and so on. For P9, his decision started rather serendipitously:

I was planning a trip. I wanted to go [abroad]. Then, on the Internet, while I was searching for travel tickets, I saw an ad for Hajj. My thought was "Why not?" It was at the beginning of the Ramadan, and one month later my mom and I went for Hajj. My mom always told me that she wanted to go to Hajj with me. I wanted to go with her as

The International Journal of Information, Diversity, \& Inclusion, 3(1), 2019

ISSN 2574-3430, https://jps.library.utoronto.ca/index.php/ijidi 
well. Plus, I had just completed years of studies away from my family. I knew I needed to go there at that point.

For P10, who had been learning about Islam and Hajj through classes, it became her personal objective:

Allah gives you the opportunity and gift to complete Hajj when the time is right. The occasion came when my dad decided to go to Hajj, I decided to go with him. At that time, I was a temp, replacing someone who was on leave [at work]. So it was the perfect time. I had no long-term commitment. ... All the signs were there. Even though, we only got the visa on the day when we left!

Like P3, P11 refers to the compulsory nature of Hajj for those who have the means. She adds: "Also, I would rather do it now that I am young and physically able, and before we had any more children [they already had a child] and when we are young."

Lastly, in the case of P12, his trigger was a cousin who had just returned from Hajj. This prompted him to take his aging mother to Hajj: "I got consent from my wife to go [to Hajj] and leave her behind. She provided support by allowing me to go to Hajj with my mother."

Once participants became actively involved in the application and preparation process, the process of imagining Mecca and the holy sites became more dynamic. Participants began more actively seeking information, stories, and advice about Hajj. Some participants' information needs were specific, such as looking for a range of information (as described below). Much of it, however, was more general, and was in the form of spiritual preparation, learning Hajj rituals, prayers, and supplications, and other Hajj logistical elements. The Kaaba, Mecca, Madinah, Mount Arafat, and Mina became imagined and desired places for all participants through the process of preparing for departure. This occurred through continuous positive reinforcement from family and friends locally and abroad in the form of lived stories, advice, and constant messaging.

\section{Step 2: Information Dissonance}

Information dissonance refers to the visceral and embodied experience of disruption and confusion created by information encounters within the receiving context (Allard \& Caidi, 2018). Although disorienting, these moments of surprise might be considered profound moments of information practice for participants. They reveal to participants the limits of their understandings and apprehension of particular issues and thus create the opportunity for further information-seeking and meaning-making to clarify or recontextualize their knowledge.

What is worth noting here is a departure from Allard and Caidi's 2018 TMM model in that, in this case, the information dissonance step starts even before the would-be pilgrims reach the holy sites. Of course, once participants arrive at Mecca, many of their Hajj-related assumptions and expectations are tested, and this happens almost immediately as participants see for the first time a physical and social environment that does not always match the picture they created for themselves prior to leaving for Hajj. However, in this study, there is evidence of dissonance as soon as the intention (niyya) was made. 


\section{Doing Hajj “the right way": Fears about invalidating one's Hajj.}

Talking about how they felt after they made their decision to complete this religious obligation, participants expressed a range of feelings from "indescribable emotions" (P6, P12), eagerness (P3, P5, P6, P8), and peacefulness (P2, P12) to a range of mixed feelings such as feeling overwhelmed (P7), nervous (P1, P11), hesitant (P3), anxious (P6, P7, P8), confused (P9), and scared (P10). The overwhelming sentiment of anxiety expressed by participants seemed to be linked to a fear of invalidating one's Hajj by not performing the rituals correctly. This obsession with completing Hajj "properly" (P2) starts as soon as the intention to go to Hajj is made, and even seems to shape the sources of information selected. P2 describes an intensive six-month process of spiritual training he undertook in order to complete the rituals for Hajj:

One needs a lot of training because rituals are full of methodology, ethics, reasons, ways of doing things properly. There is lots of what I call "religious banality": people doing things improperly. In Hajj, things are so time- and place-sensitive. During Hajj, location matters a lot. One needs lot of understanding about the geography, the timing of things. I knew stories about people who don't have guides and then miss important things. (P2)

Initially, I wanted to go to Hajj because it is a duty that Muslims are supposed to perform if they are able to. But on the spiritual side, I thought that this duty was there for a reason. I wanted to understand that meaning. There's got to be a meaning to doing Hajj. I wanted to understand that. When people talk about Hajj, often they talk about it in a literalistic manner, I wanted to understand it more deeply, not just doing the rituals. You can scratch the surface or you can go really deep. (P1)

I wanted to know everything, every little detail: the stories, all the du'as that you say there; all the actions that you need to do; all the places that you have to go to: where? at what time? What is the difference between Makkah and Madinah: what do we do in each? I wanted to know more about Mina, Muzdalifa: what is the purpose of going? The meaning of it with relation to my Hajj and my life. (P4)

I used to think that Hajj was only tawaff [circumambulation around the Kaaba], nothing else. But as I learned about Hajj, I was overwhelmed by all there was to do and what's happening there. (P7)

What is significant throughout the analysis of the pilgrims' transcripts was the omission of a concrete definition for what it means to "correctly" complete Hajj rituals. While most expressed anxiety about preparing for their journey, there did not appear to be a single source of information about how best to perform Hajj. Instead, participants relied on a variety of sources, justifying the selection of some over others.

Among the trusted sources mentioned, two seem to pervade all participants' accounts: 1) human sources, usually family members who have performed Hajj before; trusted friends who also went to Hajj, imams (community religious leaders), or the licensed Hajj travel operators who provide assistance to pilgrims with the logistics of Hajj; and 2) key religious sources: namely the Quran (Islam's holiest book) and the Sunnah (the second most important source of authority for Muslims, which encapsulates the practices, customs, and traditions of the Prophet Muhammad). These two sources of information were valued above all others when preparing for Hajj. Other sources mentioned included various books and Hajj manuals recommended by family, friends, or imams and, to a lesser extent, the Internet and electronic resources. (See Table 2). 
Table 2. Top sources of information for Hajj preparation

\begin{tabular}{ll}
\hline Sources of Information & Num \\
\hline Quran & 10 \\
Other books & 8 \\
Websites of Hajj travel guides & 8 \\
Family or relatives & 7 \\
Community leaders (including clerics) & 5 \\
Social media & 3 \\
Scholars & 3 \\
Friends & 2 \\
Other (events, Hajj classes) & 2 \\
\hline
\end{tabular}

It is particularly interesting to examine the accounts of many participants about their reliance (or lack thereof) on Internet-based resources.

I used the Internet mostly for my professional needs, at the clinic, not as much for Hajj preparation. There are so many groups on the Internet. We have the sources: the Quran, the Hadith. Whereas on the Internet, there is everything and nothing. It is better to rely on the trusted sources (my teachers, the Quran) rather than some of these sources. Again, I see the Internet as a good tool to help me with my teaching activities or my work. I also use it for travel information, when I need to access information about consumer reports and online reviews of various products and services. ... I used the Internet a couple of times while preparing for Hajj, mostly to retrieve pictures to show the kids for the course I teach at the local mosque. For the rest, I relied mostly on books and the information sessions mentioned. (P10)

Not too much use of the Internet and social media. On the Internet, there is everything and its opposite. I searched online but really quickly. I was searching for very specific questions. But I was getting all kinds of things. Mostly, I had the two books, my parents, and my family. Hajj travel agent also recommended books and gave us some resources. The ihram [clothing for men] that I took with me is from here. It was a friend's. He loaned it to me. With its scratches and all. (P9)

Books may have the information, but scholars have the proper interpretation. Having a connection with people is more important than looking on the Internet by yourself. I talked to a lot of people who went to Hajj. They recommended some Hajj tour groups to me. I talked to these people. I also went on the Internet and found reviews about Hajj tour operators. ... I also asked for books. I got some in Urdu from family members. On the Internet, I found detailed videos on YouTube. Preparation is very important. Different sources of information have to be relied on. The Internet is definitely very useful. Not just literature about rituals, but also videos about Hajj facilities, 
geographical locations, etc. There was this 2- to 3-hour video in Urdu that we came across about someone who was training people to do Hajj. (P2)

On how to tie a hijab, I went to YouTube. That's where I learned how to do it. For the abaya [women clothing], I spoke to my grandmother about it. She got the fabric for me and we got it sown. For health matters, my dad knew some things and we went to our family doctor. He helped us get prepared. My dad was my go-to source, as was my grandfather. They are the smartest around these matters. Growing up, they were very proactive about learning about their beliefs and gaining knowledge about their religion. (P4)

\section{Gendered Hajj: The missing information.}

Along with the dissonance that arises out of the desire to complete Hajj correctly and the feelings of anxiety engendered (even before one leaves for the holy sites), another information dissonance that was noted in the data had to do with the difficulty of finding gender-specific information. This concern is specifically related to female pilgrims' anxiety about invalidating their Hajj or missing out on important rituals. Indeed, while the female pilgrim seeks the same spiritual, practical, and emotional information to support her Hajj as the male pilgrim, there are also gender-specific resources that she requires before her journey. P4, for instance, worried about the extent to which her menstruation would prevent her from completing (part of) her rituals while at Hajj. Her concern is shared by several others. Some describe taking contraceptives before their flight to push back their menstruations and thus avoid missing out on rituals (Hajj rituals are done over a one-week to ten-day period, at a specified time each year):

Being a girl, I wanted to know about contraceptives. If you have your period, you cannot do a thing for a week. I was worried about this. What to do during that time? On the day of the flight, I ran to [a drugstore] with a prescription for a birth control pill. I took it right away but then I got some spotting. So I stopped taking it. Then I decided it was human nature, so be it. So I had to accept it vs. saying it was my fault. Allah gave it [periods] to me, after all. I got my period while in Madinah. So I was fortunate to have it there not during the actual Hajj. I was so stressed out about it. I made it an internal issue: It is my fault, I am a girl. What if I can't do Hajj? We forget that it is Allah's will. Lots of females in our group had the same issues. One lady took the pill for three months prior and got her period anyway despite it all. You have to let it go and accept. Go with the flow and let Allah take care of it. (P4)

P4 and others also wondered about how to tie the hijab, and other questions about the appropriate attire for females to wear. P6, who wears the niqab, expressed anxiety about having to switch to a hijab instead (during pilgrimage, one's face cannot be fully covered). She was thus worried about the appropriate way of wearing the head cover, fearing that her pilgrimage would otherwise be completed in vain:

First thing in my mind was I was scared to make mistakes actually: I don't want to make small mistakes, such as whether or how to wear the hijab or the niqab. Scholars say you cannot cover your face. Also, wudhu [ablutions]: during tawaff [circumambulation around the Kaaba], what if my wudhu is not completed? How do I get through, with that many people? Hajj is once in a lifetime, so I wanted to do things right. So I took great care in reflecting about the things I needed to do and the right way of doing things. (P6)

The International Journal of Information, Diversity, \& Inclusion, 3(1), 2019

ISSN 2574-3430, https://jps. library.utoronto.ca/index.php/ijidi 
Such findings demonstrate how gender shapes one's spiritual experiences and at times creates an additional pressure in the quest to have an authentic Hajj experience. The dissonance, in this case, comes from the difficulty of finding adequate and detailed information in official sources about the gendered nature of Hajj experience. Evidence of this situation was also seen in discussions of women as tour leaders (too few), in the requirement for a woman to be accompanied by male relative, or in the separate lines for men and women, as per participants' accounts:

All the tour leaders are men. This did not make sense to me. I didn't like that. Especially when my husband and I got separated. We had sisters' halaqas [study circles], but they were during the day, not at night. During the day, it was so hot. Often we would rest then, and go to pray and go out at night when it was cooler and less crowded. Having men as tour leaders is also an issue when you have to ask about what is to be done when, for example, you have your periods. There was one lady available for questions like that, so of course the information took longer to obtain because many wanted to speak with her or felt more comfortable approaching her than a male guide. (P7)

Muslim women need to be accompanied by a male relative during Hajj. It is the Shariaa, it is a divine law. It does not bother me. There is necessarily a reason for that. It also makes her feel safe, protected, to be accompanied by people she knows and trusts. (P10)

Restaurants had different lines for men and women. I didn't like it. I didn't want to be separated from my husband. But there were signs that said: MEN and WOMEN. I had to follow the rules. So I would stay somewhere where I could see him. He felt uncomfortable as well. ... I wish we were not separated but there are so many people, so what can we do? My husband and I communicated using our phones. We unlocked our phones and were able to buy phone cards. (P7)

\section{Information dissonance and Hajj landscape.}

Upon arrival at the holy sites, participants encounter new information continuously, through the natural environment (vegetation, temperature), the built environment (buildings, streets, geography), and in their encounters with others and with the place/space delineating Mecca's holiest sites. Almost all of participants' early arrival encounters and experiences were informational in that participants learned new things continuously, especially from their Hajj travel guides, and largely tacitly through observation, conversation, and mimicry. Information encounters in the new environment often created confusion and disorientation as participants realized that what they thought they knew didn't always "match" their own expectations of the place to which they had arrived. Interestingly, the dissonance was not always of the negative kind. One experience, in particular, was a dissonance that was also the highlight of many of the participants' journey.

\section{Setting eyes on the Kaaba for the first time.}

There are few experiences more unanimously shared in Hajj pilgrims' accounts than encountering the Kaaba for the first time. Despite having grown with memories and imagery of the Kaaba, setting eyes on the real locale for the first time (or even in subsequent trips) was a deeply moving experience for all participants interviewed, who spoke about the embodied experience of being in the same space as the Kaaba. P9 describes how the sight and presence of the Kaaba connected him with others who were doing the obligatory circumambulation around the Kaaba (known as 
tawaff) as well as all those who passed by before him:

Seeing the Kaaba for the first time. It is something that is hard to describe. Even if we have seen pictures of it since always, it just does something to you to see it in real life for the first time. Also the idea that there have always been people that circumambulate around the Kaaba 24/7 and have done so for centuries.

Many participants shared a similar sense of awe and connection:

When we got there, and humbly saw these places and saw the Kaaba, the House of Abraham, we both shed tears. We made our du'as [invocation]. It was so beautiful. (P3)

When we first saw the Kaaba and touched it, or when we were doing Safaa and Marwa [another Hajj ritual], we cried and we were both very emotional, because of the spiritual feelings that came out of being there. I don't think I will ever feel this way ever again. (P7)

\section{Hajj in the 21st century.}

While the purpose and meaning of Hajj has presumably not changed over time, the experience of it has, as modern-day pilgrimage takes place under the shadow of towering cranes, evidence of the widespread infrastructural and commercial development occurring in Mecca. The tension between consumerism and spirituality is not new at Hajj (Mecca was always a booming trading center, even in the earliest days of Islam), or at any other pilgrimages for that matter. This tension, however, takes on new forms as today's Hajj pilgrim is immersed in Wi-Fi access and smartphone apps. Pilgrims can now tweet, blog, and post photos of their Hajj experience as it unravels. Although some Hajj travelers are sometimes advised to leave technologies such as smartphones at home in order to truly detach from the world and achieve greater spiritual and mental calm, many Hajj pilgrims are not heeding those calls, choosing instead to use those technologies to stay connected, document their experience, and facilitate their rituals (Caidi et al., 2018; Porter, Haleem, \& British Museum, 2012; Tagliacozzo \& Toorawa, 2015).

The participants' accounts of dissonance have much to do with Hajj landscape, especially the crowded and built-up surroundings of the holy sites. P1, for example, was surprised and overwhelmed by how the city made her feel. She comments in these terms: "Facilities have changed considerably. My friend said that they expanded everything. The physical changes are the most striking." For many, it was a shock to see the presence of malls and fast-food chains just a few blocks away from the holy sites. P5 reflects on his initial reactions to Mecca:

Looking at it a bit critically, it is also a place where so much buying and selling is taking place. The mix of the consumer culture with the spiritual experience was disturbing. Also, the professional beggars were a reality too. You can go in and be oblivious to it. Or you see it for what it is. It reflects the inequities and hypocrisy of the times. (P5)

P9 equated Mecca to New York. He and others reflect on the pervasive use of technology in the holy sites:

In Mecca, you see many people who take pictures, even selfies, and use the Wi-Fi to go online, along with those who were happily smoking, just outside the holy perimeter. ... Mecca is more like New York. (P9)

The International Journal of Information, Diversity, \& Inclusion, 3(1), 2019

ISSN 2574-3430, https://jps.library.utoronto.ca/index.php/ijidi 
Others refer to the extremely crowded nature of the event, which comes as a shock for those who seek isolation and space for their spiritual needs. As P3 describes, "[t]hings in Hajj are hectic. It is hard to feel alone with millions of people all around you." P4 reflects on the risks associated with mass gatherings like Hajj: "Hajj is a very difficult journey. If 20 people have a cold, many others will too. The mass of people gathered makes it difficult. Patience and strength are needed. We are not used to so many people in one place." The image of Mecca that P4 and others had before departing is shattered by arrival, and must be rebuilt over time. Along with the forms of dissonance mentioned earlier, the social inequities were noted by several participants, along with the unruly behaviors of some pilgrims:

I would tell others [who are contemplating performing Hajj] that although it is a tremendous experience, a blessing, people remain humans: they shout, they swear, and get trampled. You will not always get treated well by everyone, even there. It is disheartening in a way, but people have to be more realistic. (P5)

We were saying 'alhamdulillah' [being grateful] often because next to this beautiful place, we saw people on welfare there. Here were the First World and the Third World colliding. Although we were all wearing the same ihram clothing, the cloth [for men] came in different price ranges $(\$ 60$ to $\$ 100)$. It was very visible. We stayed in different places. It is supposed to be a reflection of the afterlife [when everyone is same and equal in front of God], but not so much. I could tell if someone was wearing an ihram that is polyester, or a bedsheet, or $100 \%$ cotton. There were many different fabrics. Some of the women are wearing a uniform (jabab) and it said on it "Welfare" [e.g., their Hajj was financially supported]. They would stay in more precarious places. There was also that reality. (P7)

This clash between the expected Hajj and the reality on the ground (the built-up environment, the pervasiveness of technologies, the social inequalities and diversity of the Muslim Ummah) was often filtered through the eyes of the 12 participants, most of whom lived in the West. One participant, however, provides an interesting nuance to his observations:

From a Western perspective, we are coming from a particular standing. We don't necessarily want to see our own reality and lifestyle replicated when we are going to do Hajj. Whereas, for people from other parts of the world, that pilgrim will have positive experience of Hajj specifically because of the tiled floors, the air conditioning, the McDonald's, the tall hotels, etc. For some of us, that is a negative thing. We don't want to see so much similarity with our daily environment. For others, it is not. I can imagine it being quite incredible for people coming from elsewhere, a poorer country, and for them this would be a positive thing, a part of Hajj experience. (P5)

Taken together, these accounts suggest a certain dissonance between the 12 participants' expectations of the pilgrimage and their lived experiences on the ground while at the holy sites. This step prepares the participant for the next one, which is an increased understanding of Hajj landscape.

\section{Step 3: Increasing Sophistication and Understanding of Hajj Information Landscape}

The third step of the TMM process refers to participants' increased understanding of Hajj information landscape. Indeed, participants' direct encounters and experiences with Hajj-based information landscapes assists them in contextualizing and making sense of the information and 
advice they received from their social network ties, Hajj travel guides, and through their own preparations. Going through the motions alongside other pilgrims, and coming face to face with the objects and sites, also contributes to an embodied understanding of what it means to be a pilgrim.

As has been evident from the previous sections, preparing for Hajj involves a series of stages encompassing both material and spiritual dimensions. Upon arrival to Saudi Arabia (usually at Jeddah International Airport), a pilgrim has to undertake a prescribed set of rituals with specific supplications and actions associated with each location. Timing is also critical as pilgrims have to spend designated amounts of time in specific locations before they are to move to the next, for which once again, a specific set of actions, salutations, and prayers are to be completed. Outside these rituals that are the core of the pilgrimage per se (and that "validate" Hajj), more time is spent at a more leisurely pace at a few other locations, most notably Madinah, which does not encompass any required rituals per se but where pilgrims usually go to visit Masjid alNawabi, one of the holiest mosques in Islam. Madinah is also a favored shopping destination for pilgrims (gift-giving also being an important aspect of Hajj).

In preparing for Hajj, however, an understanding of these rituals is only the tip of the iceberg (albeit a key component), there are also logistical matters that need to be arranged such as obtaining a Hajj visa and making local arrangements. This can only be done through a qualified Hajj travel agent that has been pre-approved by the Saudi government. The certified travel agents (also called Hajj tour operators, Hajj travel guides, or mutawaffs) are responsible for providing their clients with travel visas, with transportation and accommodation arrangements, and often with an Imam or a guide on site that can assist the pilgrims with questions and take them through the rituals. In reality, there is a vast difference in the quality of services provided by these travel agents. Participants often seek recommendations from friends or community leaders about reputable Hajj travel operators (when that choice is available). Many participants referred to the selection of a Hajj travel agency as a key aspect of one's pilgrimage. Word-ofmouth and online reviews of agencies are often rigorously conducted for making such a decision.

It is worth noting that the other key dimension of Hajj preparation-the spiritual aspect-used to fall on Hajj travel guides too, but is no longer something that falls squarely within their purview alone. Depending on where the pilgrim hails from, they may rely solely on Hajj travel guides for preparation in the spiritual realm (how to prepare to be in "that state"; What should I avoid doing prior to Hajj? What do I need to recite to validate my Hajj at the different stages? etc.). It is fair, however, to say that most pilgrims in this sample did not rely solely on Hajj travel guides for the spiritual aspect of their journey. Instead, as exemplified by the excerpts below, the 12 pilgrims used a variety of sources for the most part (i.e., the Quran and the Hadiths, speaking with family and friends, other Hajjis or their religious leaders, or browsing through Internet sites):

We talked to our Hajj travel specialists. When it comes to logistical matters, it is a very guided process, so we did not worry about that. Hajj specialists provided lots of useful information about that aspect. Hajj documentaries were available on [a provider's] website. I also spoke with my mother who gave me small booklets of du'as. My husband was not too involved with logistical preparation but big time into the spiritual preparation. He recommended books to read-about the meaning of Hajj that he had read. He shared resources and knowledge about various aspects of Hajj. (P2) 
I mostly spoke to my mother. She did Hajj ten years ago, but it was still fresh in her mind. I talked to her about the meaning of Hajj, its reward and importance. She was a strong motivator and helpful about the rituals and how to do them properly. I correlated these with other sources. The tour operators were also very experienced. (P3)

I consulted books that were recommended to me for the invocations, rituals, and the why of Hajj. I went to workshops organized by Hajj travel guides: for rituals and what to do and say when, but not for the meaning of Hajj, the why. They were also good for the logistical aspects, the itinerary and what to expect. I spoke with friends and family for the sharing of experiences, the lived experience, the emotional part, for example seeing the Kaaba for the first time. It is something that is hard to describe. ... I spoke to imams too, for the spiritual guidance and religious questions, the why. (P9)

According to Allard and Caidi (2018), during this third TMM step, participants' information practices usually evolve from general, nonspecific, and very dependent on a few resources to explicit, independent, and considerably more sophisticated. In this study, participants' information strategies were often quite reliant initially on Hajj travel guides and on the general information they had gleaned about the rites and rituals for the different stages of Hajj. As the participants became more familiar with the environment, however, they became more autonomous, and expressed that they worried less about the logistics and the material aspects of their journey and focused instead on other aspects of their Hajj. P3 recounts:

Things in Hajj are hectic. Information-wise, the information was given to us as we went along the journey. It is hard to prepare with millions of people around you. ... The first day we arrived, the tour leader showed us how to do the tawaff [around the Kaaba] and how to say the du'as. After the first time, we just went to the Kaaba and did our own thing. After the tour leader did their thing, we didn't stick to that preparation anymore. It takes a lot of time for older people to complete obligations or to gather together all at the same time to do things. We would soon do our own thing. We would go anytime we wanted. We read the Quran around the Kaaba. We joined other groups (Turks, Iranians) and I liked following them sometimes and we chanted with them. (P3)

Other participants also reported that much of the information about daily life at Hajj was initially acquired tacitly as they observed and mimicked the daily practices of their fellow pilgrims. At that stage, participants also mentioned that they required significant assistance with navigation and interpretation of Hajj information landscape. By the end, however, through going through the acts, observing, and imbibing from the local setting, participants gained confidence and learned the ropes. Some came to reflect upon (and sometimes reconsider) their expectations and even the advice provided to them. Like information dissonance, this step occurred iteratively and unevenly across participants' accounts of their pilgrimage. P5 describes his reflections (retrospectively) on the role of Hajj travel guide in contemporary Hajj:

I have gone on to websites providing Hajj services for Western Muslims. When I see the different services they provide, much of it, I feel, is not essential. It is a little misleading to think that all this privilege and luxury is required. All these luxuries, the special packages, etc., are made to be or to feel necessary (by saying it is hot or it is crowded so you need all these things). It is almost common sense. But Hajj in some ways is just like when you start planning for a wedding: you want nothing to go wrong. But I feel that a level of struggle makes it more meaningful. But people want the luxury or they think

The International Journal of Information, Diversity, \& Inclusion, 3(1), 2019

ISSN 2574-3430, https://jps. library.utoronto.ca/index.php/ijidi 
they need it because they are heading to a foreign land. So the role of these guides is to make their journey possible. (P5)

P8 describes how her lived experiences of the holy sites (re-)shaped her views about preparing for Hajj:

You have to prepare, for sure. You definitely need to know what you are doing. It makes it easier, for sure. But I wish that when people do these [preparation] seminars, they would discuss more the special moments, or the being in the moment. Because when you do Hajj, time goes by so fast, and next thing you know, you are done. It is an obligation, there are rules and things you need to do, but it is also very good for your heart if you take your time and get that connection. That is what will stay with you. The spiritual and emotional connection. The first time, I had no physical preparation, and it was hard! But, I was 17. It was hot. It was a test. The second time, I prepared differently. I did not worry so much about getting it wrong. (P8)

As can be seen, preparing for Hajj is a long and potentially arduous task that starts as soon as one makes the intention of going for Hajj and includes material, spiritual, emotional, as well as logistical preparation. Participants exhibited a range of practices that informed their learning before as well as during Hajj, all of which contributed to providing them with a deeper and everevolving understanding of the meaning of Hajj in their lives.

\section{Step 4: Re-imagining Mecca and Hajj}

In the fourth step of the TMM process, participants engage in ongoing reflection and reconsideration of the imaginaries around Hajj based on their lived experiences and what they brought back with them from the holy sites. Goals and expectations are adjusted or rethought based on growing experiences and a greater awareness and understanding of the local context in the holy sites. Participants retuned their expectations of what it means to be a pilgrim through their evolving experiences, perceptions, and feelings.

\section{Re-imagining one's position within a broad and diverse Ummah.}

A striking finding in participants' accounts has to do with their positionality as part of a broader global narrative about "Muslimness," and more broadly about being human. After he spent one month at Hajj, P6 recounts:

I was amazed at how Allah treats you the same. Everyone is at the same level. You cannot feel that one is from here or there when at Hajj. We are all the same in front of Allah. The lady cleaning the place is standing next to you. We are the same. We are nothing. We are all the same on this Earth. We don't know who is good in front of Allah's eyes. Here, we stress about hygiene, cleanliness, etc. But in Arafat, these things don't matter. In Arafat, we sit on rocks and sand. Both the kings and the poor. All the same.

P6 situates his own journey and experiences within a broader context of Islamic culture and history. His experience is both connected to other narratives of Hajj and speaks back to and clarifies these narratives. In this study, participants located their Hajj narratives in a context of global diasporic networks based on their newly acquired experiences: 
I didn't think much about it at the time. Although I did feel this sense of connectedness with other Muslims even then. As Muslims in the West, we sometimes feel disconnected from other Muslims and when I was standing there, I felt very connected at that point. When people walk the plains of Muzdalifah, scores of people as far as the eye can see. That image stayed with me. It was like the Day of Judgment when everyone is gathered in front of God. (P5)

[Hajj] made me grow up and have a consciousness about what kind of person I wanted to be. I am trying to be that better person every day. I keep going back because it is not enough. There is a peace, a settled feeling when I am there. There is not a place more peaceful than Madinah. (P8)

The essence of the journey remains mysterious. Hajj is a blessing. And it also made me realize that I was interested in this broader humanity, and curious about some aspects of Islam now, like Sufism. (P3)

\section{Understanding Hajj relationally.}

In the same way that Hajj is re-imagined through participants' experiences at the holy sites, so, too, the return home is rethought and re-imagined. Participants draw from their experiences as well as others' narratives about the return from Hajj to reformulate their impressions of their local contexts. As P9 eloquently puts it:

When we are there, we become aware of certain things. The truth is what we are living now and here. The rest is all powder in the eyes. What really changed me, in me, is that I really detached from the material aspects of life. I have already changed since I returned from Hajj, because when you are surrounded by this environment, you need a tune-up. I see Hajj as being like a gas station to allow you to fuel up a bit. There is this life and the life in the hereafter. One should enjoy life's pleasures but not forget to invest in the hereafter. If I don't have any gas left, I need to fill the tank again and put more fuel to replenish. I feel that I was always running on empty before. Sometimes I had a rush, but since I have been to Hajj, it has become a therapy. I have spoken to friends of mine, and when they ask me about Hajj, I always talk to them about these benefits. (P9)

This recasting is most evident when participants draw comparisons, as they so frequently do, between here and there (Mecca and back home). Indeed, the holy sites and the return home were most often described and understood relationally, as extensions rather than comparisons of each other:

Because I am a travel agent and in the tourism business, now if someone asks me about pilgrimage, I can reflect on the experience. It is a journey, and you meet God and learn things. People teach you and you teach people. It enriched me in that way too. (P3)

You are expecting a bus at Muzdalifah and the bus is coming 4 hours late. Hajj teaches you patience. Despite where you come from, you should learn how to behave. Patience is the essence of Islam. The life of the Prophet was all about patience. It taught me patience at work too. I am looking for a job now. My contract is coming to an end. But I am composed. I am comfortable because I don't remember a day in my life when I lived without a roof over my head, or went hungry. When I am being impatient, I go back to 
my God by praying and focusing on the meaning: what am I actually doing and how am I praying? It reconnects me. We have to learn the lessons and the meanings behind it. What can I improve? There is more consciousness than before. Sometimes it feels that it faded, but I work on it. (P2)

One of my favorite memories was being on the third floor of the mosque [in Mecca] and looking at birds making du'as. And I remember thinking: "here I am here, 17, and my Prophet was here." You feel connected. This is me. I am so far removed from him, but I am not. There was such a strong connection. (P8)

\section{Step 5: Social Imaginary of Becoming a Hajji/Hajja and the Return Home}

In this last step of the TMM process, the social imaginary of both the pilgrimage and the return home shifts as participants contribute their own pilgrimage experiences and narratives back into their social settings. This shift occurs as participants tell their own pilgrimage stories to their social network ties and to potential pilgrims. These Hajj stories being passed on encapsulate the participants' own meaning-making around their situated Hajj experiences. Indeed, once participants return home, they are frequently contacted by friends and family, seeking information, support, and advice about pilgrimage to Hajj. P6 and P8 describe the responsibility that comes with the new status:

Initially, when I came back, I was aware [of Hajja status]. People call you "Hajja” at 17. And I thought I was that, and it made me feel that I had to act a certain way. Moms used me as an example that I was setting, and I didn't like it. But, dealing with the hardship [of Hajj], you learn to be patient, I utilize this attitude in my social interactions. (P8)

We [pilgrims] have completed something very important, and we have to hold on to that, to be responsible, accountable. With time passing, it is easy to be attracted again into these other [worldly] things. Before Hajj, I was depressed after I had returned from my studies abroad. I was not employed, was seeking work. I didn't feel that I belonged back home. So it was 2 to 3 months of depression. While in Mecca, I was serene, rested in my head, so I didn't want to come back to what I used to be before. By going to Hajj, I was able to assess my situation at home. I realized that if I have to be in this place [his hometown], I needed to try harder than that. (P9)

The status of Hajja is important in our community. So, one has to preserve that image, and the responsibilities that come with it: you cannot go dancing, can't go to mixed gender weddings, etc. One hears of these remarks "She is a Hajja." It becomes problematic for youth, especially girls, because they start thinking that they are not ready to go to Hajj because then they will no longer be able to do this or that. After a few months, one forgets: the emotions, the journey, the memories, the acts of adoration, the encounters. We are back in the everyday grind. So we try to plan ahead for the next trip there. ... So, I was a "Hajja," yes. It was an even bigger deal in Morocco, when I went to visit. It mattered even more there. It was a prestigious status. But I did Hajj for myself, and for Allah. Not to get Hajja status. (P10)

Participants also shared their strategies for coping with the return and the rapture with the serenity of the holy sites: 
When I am at home, I feel OK. But outside, it is very different and it is hard. So, I sit for a few moments, thinking about that journey; how I practiced there; how my life changed when I was there. There is this one channel, al Mubashir [a Saudi livestreaming channel of Hajj]. I put it on my computer and concentrate on that and it makes me very energetic. It helped me a lot since I returned. I see the live transmission of Hajj and it reminds me of my own experience there. (P6)

Before Hajj, I didn't do any overly Islamic art form. I started to explore more after my first Umrah. It is not exactly calligraphy, but I started exploring Islam and art together. (P8)

I came back depressed. There, we were all surrounded by other Muslims. When I returned, I felt lost, nostalgic, depressed. I used the satellite dish to watch Saudi Arabia channels, especially scenes of Mecca, and to remember. It was like a sanctuary. (P10)

The notion of "sanctuary" made possible by media consumption and practices is more than a coping mechanism; it seems to point to the importance of objects and artefacts in the lives of pilgrims. Their materiality was meaningful and tied to the spiritual/religious and emotional experience of the pilgrims. Indeed, the embodied experience at the holy sites seemed to have found an expressive release through the practice of recording and documenting their Hajj either in the form of diaries or through photographs and videos. These documentary practices were deemed helpful for the pilgrims to remember and retrieve the state they were in while performing Hajj or Umrah. For P1, keeping a diary during Hajj allowed her to make sense of her pilgrimage journey:

I wanted to understand the spiritual dimensions of Hajj: the true meaning of it, beyond the rituals. I kept a journal to remember. I highly recommend it. I made the decision to keep it private and it was a very valuable experience. I got this idea of a journal from a blog actually from a North American woman called “Ten things you didn't expect about Hajj." It is actually very common to see people write their diaries at Hajj. We saw people doing that all the time. It is the small things that you need to absorb while there. That's why you keep it. (P1)

P3 took videos and photographs to document his Hajj. However, when he shared these with some of his relatives, he was faced with an unpleasant comment that made him reflect further about his practice:

I was showing my cousin what I videotaped around the Kaaba. He or someone said: “I thought this was a journey between you and God, why would you show me this? You are showing this on YouTube and to your family on the computer. Why?" I was angry inside at this comment. My thought was to bring a memory from when I did it. To show the Kaaba both for myself and to share. We are living in the age of technology, and we live with it. I could see how it can take away the spiritual. A bit. It reduced the impact a bit. We [he and the other Hajjis in his group] didn't really talk about it [the filming, videotaping]. It was just something we did. We just had the video camera and the camera and we used it. We saw people filming. Everyone had a cellphone to communicate with the outside. They even took selfies. I did it too. This was an important place and we wanted to document that. (P3)

P3's sense-making about the role of images at Hajj exemplifies the kind of narratives that will

The International Journal of Information, Diversity, \& Inclusion, 3(1), 2019

ISSN 2574-3430, https://jps. library.utoronto.ca/index.php/ijidi 
start circulating as a result of lived experiences of Hajj for modern-day pilgrims like him. In this and other ways, participants' lived experiences reshape that of the next generation of pilgrims in the same way that the experiences of those who came before the study participants affected their expectations and associated information practices. This last step of the TMM process articulates the shifting roles and positions of participants as they performed Hajj and returned changed. Over time, they, in turn, become key sources of information that contribute to shaping imaginaries of Hajj for other potential pilgrims through both their stories and their practices.

\section{Discussion}

This article examined Hajj pilgrims' meaning-making practices as they journeyed to Mecca, Saudi Arabia, completed Hajj, and returned home with experiences and stories to tell. Adapting Allard and Caidi's (2018) TMM model, it was possible to show how the participants actively and individually engaged in producing meaning out of the socially located information they encountered within their information environments. For them, pilgrimage-related information practices were both iterative and dynamic, shifting from imaginary to experiential and back again as these pilgrims gained an understanding of Hajj landscape, how it transformed them, and how they fit in it. Meaning-making is thus both deeply individualized (derived as it is, experientially and emotionally) and embedded within social relations, contexts, and imaginaries (Allard \& Caidi, 2018).

In this study, the participants moved through Hajj preparations and its completion in a fluid manner, and returned having been transformed by these other locations, experiences, and encounters: encounters with the self, with the land, with history, with a diverse and complex Ummah, with the infrastructures of Hajj, and with both the material and the spiritual. How Hajj pilgrims navigated these unknown information contexts, with resources, strategies, and sensitivities forged by their local and varied information environments, is precisely what informs their TMM process. Their multiple and sometimes conflicting ways of knowing and of doing things highlight the diversity in transnational knowledges and skills that pilgrims deploy as they engage in their Hajj journey.

As Allard and Caidi (2018) point out, "moments of dissonance provide intellectual and affective 'space' for learning and meaning making" (p. 1200). The notion of information dissonance in this study was found to be even more fluid than initially conceived by Allard and Caidi, who refer to its deployment at the outset (upon arrival to a new country, in the case of Filipinos migrating to Winnipeg). In this study, there is evidence that dissonance can occur at any point even before the journey starts, thus signaling further the deeply embedded nature of information practices with human emotions.

This study also sheds further light on spiritual information practices and their embodiment into practice. As mentioned, information studies scholars need to pay more attention to the spiritual realm when it comes to everyday life information practices. In this study, there is evidence that information in the spiritual realm is found to be imparted through a range of information practices from stories shared by other pilgrims, visual imagery, the materiality of objects, through encounters and wandering, as much as by reading and searching texts. The knowledge about what it means to be a pilgrim is thus constituted holistically within situated rituals and embodied practices. Learning to be a pilgrim is connected to the act of performing physical acts, engaging in rituals, saying invocations, and reading the holy landscape to find one's own meaning.

There are lessons and implications for information studies scholars and professionals about the

The International Journal of Information, Diversity, \& Inclusion, 3(1), 2019

ISSN 2574-3430, https://jps.library.utoronto.ca/index.php/ijidi 
value of examining transformational experiences such as the pilgrimage to Mecca. As examples of spiritual and/or contemplative aspects of human existence, transformational experiences are found in every culture and provide grounds for building bridges between people and between cultures. Libraries, archives, museums, art galleries, and other such institutions are ideally suited to harness the power of transformational experiences as a means of facilitating transcultural affinities as part of their mission to increase diversity and inclusion.

\section{Conclusion}

Completing a pilgrimage (whether spiritual, religious, or otherwise) has often been touted as a transformational experience. Yet, pilgrimage as an information context is sorely lacking in our field, despite the valuable insights it could provide into the complex information environments and evolving states of those who undertake pilgrimage. In this study of Hajj, the experiences of 12 pilgrims were detailed through the examination of the material, spiritual, and informationrelated dimensions of their Hajj. Applying the lens of pilgrimage as "lived religion" rendered explicit the detailed activities and outcomes of pilgrim information practices and the ways in which information in its multiple forms (textual, spiritual, corporeal, etc.) mediated and shaped the pilgrims' journey. In doing so, this article invites information studies scholars to refine the research agenda around spiritual and transformational experiences (including but not limited to pilgrimage) and engage with questions such as the ones outlined in Caidi and Innocenti (2018) that invite us to reflect on our field's contributions to new ways of thinking about pilgrimages and other transformational experiences; on exploration of pilgrimages and other transformational experiences that take into account the current global and networked environment, and/or reflect the realities of migration and diasporic identities; along with the evolving role of cultural and memory institutions as resources on, and sites for, the commemoration of transformational experiences.

\section{Acknowledgements}

The author wishes to express her gratitude to the research assistants who contributed to this project at the Faculty of Information, University of Toronto: Ms. Adrienne Phillips and Ms. Elisa Tate. The author also thanks Dr. Perla Innocenti for the stimulating conversations at the early stages of manuscript development.

\section{Endnotes}

\footnotetext{
${ }^{1}$ Umrah is an optional pilgrimage to Mecca that can be undertaken at any time of year. While most rituals are the same as those for Hajj, other requirements are not there during Umrah, such as the specific clothing (the ihram worn by men), the sacrificial slaughter of an animal at the end of the Hajj, or the cutting of hair. Lastly, the pilgrim undertaking the Umrah is not conferred the title of a Hajji/-a upon completion of his/her pilgrimage. In our study, many pilgrims performed the Umrah in addition to the Hajj.

2 The recruitment stage may seem unusually long but points to the difficulty to recruit members of vulnerable communities, as is the case with young Muslims in a post-9/11 world,
} 
when there is a great reluctance to engage with the media or scholars when Muslims and Islam are often portrayed as either villains or potential threats. Moreover, because of my focus on Hajj pilgrims aged 18-35, the proportion of young Muslims who have completed the Hajj was also smaller than if I had selected a broader sample. It must be noted that the ethics were renewed regularly throughout this data collection.

${ }^{3}$ As the number of pilgrims continues to grow, resulting in strain on the infrastructure, the Saudi Ministry of Hajj along with the Organization of Islamic Conference passed a resolution to specify a system of quotas for each country according to its population (one pilgrim for each 100,000 inhabitants). In heavily populated countries, such as Indonesia, this represents a considerable waiting time for would-be pilgrims, who have to wait for their turn. Lottery systems are also in place in some countries.

\section{Appendix - Interview Guide}

Part I: Tell Us About Yourself

The following questions are for analytic purposes only.

1. In what country were you born?

2. In what year did you first come to Canada?

3. Besides Canada (and your country of birth) have you lived in any other countries for 3 years or more?

$$
\begin{array}{ll}
\text { 1. Yes - go to question } 4 & \text { 2. No - go to question } 5
\end{array}
$$

4. Which countries were these?

5. What was the language that you first learned at home in childhood?

6. Besides the language of interview and your first language, are there any other languages that you speak well enough to conduct a conversation?

1. Yes - go to question 7

2. No - go to question 11

7. What languages are these?

8. What language do you speak the most often at home?

9. What languages do you speak most often with your friends?

10. Are there any other languages you speak on a regular basis?

1. Yes - please specify which: 
2. No

11. What is your marital status?

$$
\begin{array}{ll}
\square & \text { single } \\
\square & \text { married } \\
\square & \text { divorced } \\
\square & \text { separated } \\
\square & \text { widow/ed }
\end{array}
$$

12. What was your age on your last birthday?

18-24 years

25-29 years

30-35 years

13. Gender:

$$
\begin{array}{ll}
\text { a } & \text { Male } \\
\text { a } & \text { Female }
\end{array}
$$

14. My ethnic background is:

- South Asian /Asian Canadian

- Middle Eastern/Arab

- Black/African Canadian

口 Hispanic/Latin

- Caucasian

- Native Canadian/First Nations

Other: (Please specify):

15. What is the highest level of education you have achieved? [Circle one answer] I am a(n):

\ Undergraduate student

口 Graduate student

Other: (Please specify): 
16. What was your most recent employment status?

[Interviewer: Read list. Circle one item and fill in information for that item]

口 Employed

\ Self-employed

a Student

at home

口 Unemployed

a Other

Part II: Your Perspective on Islam and Hajj

The next series of questions ask about your opinion about Islam and your decision to go to Hajj.

1. Would you consider yourself as someone:

a Deeply religious and/or spiritual

- Moderately religious and/or spiritual

- Mostly spiritual but not religious (i.e., does not pray, fast, etc.)

\ Not very religious nor spiritual

Other. Please Specify:

2. As a self-identified Muslim, what are your main source(s) of information about Islamrelated matters? (Select all that apply)

- The Quran and associated texts (Hadiths, etc.)

- Original text or Translations/Interpretations?

- Family and/or relatives

口 Community leaders (imams, etc.)

Griends and peers

․ Books

- Mass media (radio, TV, newspapers, etc.)

Mailing lists

口 Social media (Facebook, blogs, wikis, etc.) 
a Websites

- Word of mouth

을. Please Specify:

3. Growing up, what were your recollections of Hajj, the pilgrimage to Mecca (i.e., what did you associate it with?)?

4. Has anyone in your immediate circles (family, relatives, friends) completed Hajj?

- Yes (if so, who and when?):

․ No

․ Not sure

5. Have you completed Hajj or Umrah?

Y Yes (if so, when?):

- Not yet (if so, when do you plan to?):

6. Do you remember a specific moment when you knew you wanted to complete Hajj? (i.e., was there a trigger?)

7. How did your family and friends respond when you told them you wanted to/were going to complete Hajj?

8. After you made the decision to complete Hajj, how did you feel?

9. At that time, what did you think that you needed to know in order to prepare for the pilgrimage to Mecca? (if has not completed Hajj yet: "what do you think that you need to know...")

10. What did you actually do to prepare? (i.e., how did you go about preparing for Hajj?) -If has not completed Hajj yet: "what are you actually doing to prepare?"

11. Did you talk to, or consult with, anyone during the preparation phase? If yes, whom? (rank them by order of importance)

12. Have you ever attended meetings organized to learn more about Hajj?

- No, I have never attended a meeting. [Go to \#13]

- Yes, I have attended such meetings. Such meetings were (or are being) held:

- Once a week or more

○ Once a month

○ Once a term

The International Journal of Information, Diversity, \& Inclusion, 3(1), 2019 
Once a year

13. Who organized such informational sessions?

- Hajj specialists such as tours and travel agents.

a Co-religionists (who performed Hajj)

- Religious leaders (at mosques, organizations, etc.)

a other

14. Did you consult any electronic resources during your preparation for Hajj?

口 Yes (which ones?)

No (why not?)

15. What proved to be the most useful resources to help you prepare for Hajj? Why?

16. Did you access any Hajj-related materials in languages other than English? Why did you choose these? What was the most useful feature about them?

17. What are the top three (3) resources that you would recommend to someone going to Hajj?

18. What has changed for you in your personal life since you completed (or decided to undertake) Hajj?

19. What has changed for you in your professional life since you completed (or decided to undertake) Hajj?

20. What lessons have you learned with regard to preparing for Hajj?

21. Is there anything else that you would like to add?

\section{References}

Allard, D. (2015). Living "here" and "there": Exploring the transnational information practices of newcomers from the Philippines to Winnipeg (Doctoral Dissertation). Retrieved from ProQuest Dissertations \& Theses Global. (Order No. 3746239)

Allard, D., \& Caidi, N. (2018). Imagining Winnipeg: The translocal meaning making of Filipino migrants to Canada. Journal of the Association for Information Science \& Technology, 69(10), 1193-1204.

Appadurai, A. (1996). Modernity at large: Cultural dimensions of globalization. Minneapolis, MN: University of Minnesota Press.

Badone, E., \& Roseman, S. (Eds.). (2004). Intersecting journeys: The anthropology of 
pilgrimage and tourism. Urbana, IL: University of Illinois Press.

Bati, G. (2015). Using big data tools to analyze tweets related to Hajj sentimentally. Proceedings from the 15th Scientific Symposium for Hajj, Umrah, and Visit, Madinah, Kingdom of Saudi Arabia.

Bell, G. (2006). No more SMS from Jesus: Ubicomp, religion and techno-spiritual practices. In P. Dourish and A. Friday (Eds.), Ubicomp 2006, LNCS 4206 (pp. 141-158). Berlin: SpringerVerlag.

Brickell, K., \& Datta, A. (Eds.). (2011). Translocal geographies. London: Routledge.

Buitelaar, M. (2015). The Hajj and the anthropological study of pilgrimage. In L. Mols \& M. Buitelaar (Eds.), Hajj: Global interactions through pilgrimage (pp. 9-25). (Mededelingen van het Rijksmuseum voor Volkenkunde 43). Leiden, NL: Sidestone Press.

Caidi, N., \& Innocenti, P. (2018). On being spiritual: Pilgrimage as an information context. Panel session at the Information Seeking in Context (ISIC) conference (October 9-11, 2018). Krakow, Poland.

Caidi, N., Beazley, S., \& Colomer Marquez, L. (2018). Holy selfies: Performing pilgrimage in the age of social media. International Journal for Information, Diversity and Inclusion (IJIDI), 2(1/2), 1-25.

Carneiro, M. J., Eusébio, C., \& Santos, A. C. (2016). The emotions generated by re-enactment events: A market segmentation study of the medieval journey in the land of Saint Mary. Journal of Convention \& Event Tourism, 17(3), 192-219.

Clingingsmith, D., Khwaja, A., \& Kremer, M. (2009). Estimating the impact of the Hajj: Religion and tolerance in Islam's global gathering. The Quarterly Journal of Economics, 124(3), 1133-1170.

Coleman, S. (2002). Do you believe in pilgrimage? From communitas to contestation and beyond. Anthropological Theory, 2(3), 355-368.

Coleman, S., \& Eade, J. (2004). Reframing pilgrimage. Cultures in motion. London: Routledge.

Coleman, S., \& Elsner, J. (1995). Pilgrimage: Past and present in the world religions. Cambridge, MA: Harvard University Press.

Corbin, J. M., \& Strauss, A. (2007). Basics of qualitative research: Techniques and procedures for developing grounded theory (3rd ed.). Thousand Oaks, CA: Sage.

Eade, J., \& Sallnow, M. (Eds.). (1991). Contesting the sacred: The anthropology of Christian pilgrimage. London: Routledge.

Eade, J., \& Sallnow, M. (Eds.). (2000). Contesting the sacred: The anthropology of Christian pilgrimage $\left(2^{\text {nd }}\right.$ ed). Urbana, IL: University of Illinois Press.

Edensor, T. (1998). Tourists at the Taj. London: Routledge. 
Elsner, J., \& Rutherford, I. (2005) Pilgrimage in Graeco-Roman \& early Christian antiquity: Seeing the gods. Oxford: Oxford University Press.

Essoo, N., \& Dibb, S. (2004). Religious influences on shopping behaviour: An exploratory study. Journal of Marketing Management, 20(7-8), 683-712.

Flaskerud, I., \& Natvig, R. J. (2018). Muslim heritage in Europe. London: Routledge.

Frey, N. (2004). Stories of the return: Pilgrimage and its aftermaths. In E. Badone \& S. Roseman (Eds.), Intersecting journeys: The anthropology of pilgrimage and tourism (pp. 89-109). Urbana, IL: University of Illinois Press.

Freeman, L., \& Bell, S. (2013). Women's magazines as facilitators of Christmas rituals. Qualitative Market Research: An International Journal, 16(3), 336-354.

Gaston, N. M., Dorner, D. G., \& Johnstone, D. (2015). Spirituality and everyday information behaviour in a non-Western context: Sense-making in Buddhist Laos. Information Research, 20(2), paper 665. Retrieved from http://www.informationr.net/ir/202/paper665.html\#.XE3ZL89KgXo

Gorichanaz, T. (2016). Experiencing the Bible. Journal of Religious \& Theological Information, 15(1/2), 19-31.

Guzik, E. (2013). The search for meaning: Information seeking and religious conversion. Advances in the Study of Information and Religion, 3(5). Retrieved from http://digitalcommons. kent.edu/asir/vol3/iss1/5

Innocenti, P. (2015). Cultural networks in migrating heritage. Intersecting theories and practices across Europe. Oxford: Routledge.

Innocenti, P. (2016). Cultural networks and social inclusion of migrants in Europe: Heritage, ICT, and participatory governance. International Information \& Library Review, 48(4), 274-286.

Janin, H. (2002) Four paths to Jerusalem: Jewish, Christian, Muslim, and secular pilgrimages, 1000 BCE to 2001 CE. Jefferson, NC: MCFarland.

Kari, J. (2007). A review of the spiritual in information studies. Journal of Documentation, 63(6), 935-962.

Kari, J., \& Hartel, J. (2007). Information and higher things in life: Addressing the pleasurable and the profound in information science. Journal of the American Society for Information Science \& Technology, 58(8), 1131-1147.

Kingdom of Saudi Arabia, General Statistics Authority. 2018. Limited to actual Haj. Retrieved from https://www.stats.gov.sa/en/28

Lambert, J. (2010). The information-seeking habits of Baptist ministers. Journal of Religious \& Theological Information, 9(1/2), 1-19.

Liebelt, C., Shenar, G., \& Werbner, P. (2010). Migration, diaspora, and religious pilgrimage in 
comparative perspective: Sacred geographies and ethical landscapes. Diaspora: $A$ Journal of Transnational Studies, 19(1), 32-50.

Lloyd, D. W. (1998). Battlefield tourism: Pilgrimage and the commemoration of the Great War in Britain, Australia, and Canada. Oxford: Berg.

Michels, D. (2012). Seeking God's will: The experience of information seeking by leaders of a church in transition. Canadian Journal of Information and Library Science, 36(1-2), 1627.

Minton, E. (2018). Believing is buying: Religiosity, advertising skepticism, and corporate trust. Journal of Management, Spirituality \& Religion, 2, 1-22.

Mols, L., \& Buitelaar, M. (Eds.). (2015). Hajj: Global interactions through pilgrimage. (Mededelingen van het Rijksmuseum voor Volkenkunde 43). Leiden, NL: Sidestone Press.

Norman, A. \& Cusack, C. M. (2015). Religion, pilgrimage, and tourism. London: Routledge.

Porter, V. \& Abdel Haleem, M. (Eds.). (2012). Hajj: Journey to the heart of Islam. London: British Museum Press.

Post, P., \& van der Beek, S. (2016). Doing ritual criticism in a network society. Online and offline explorations into pilgrimage and sacred place. Leuven, BE: Peeters Publishers.

Roland, D. (2012). The information behavior of clergy members engaged in the sermon preparation task: Wicks revisited. Journal of Religious and Theological Information, 11(1/2), 1-15.

Roland, D., \& Wicks, D. (2010). A conversational model for qualitative research: A case study of clergy and religious knowledge. Australian Academic and Research Libraries Journal, 40(1), 252-265.

Ross-Bryant, L. (2017). Pilgrimage to the national parks: Religion and nature in the United States. New York: Routledge.

Sallnow, M. (1981). Communitas reconsidered: The sociology of Andean pilgrimage, Man, 16, 163-182.

Savolainen, R. (1995). Everyday life information seeking: Approaching information seeking in the context of way of life. Library \& Information Science Research, 17(3), 259-294.

Savolainen, R. (2008). Everyday information practices: A social phenomenological perspective. Toronto, ON: The Scarecrow Press.

Savolainen, R. (2016). Approaches to socio-cultural barriers to information seeking. Library \& Information Science Research, 38(1), 52-59.

Tagliacozzo, E., \& Toorawa, S. (Eds.). (2015). The Hajj: Pilgrimage in Islam. New York: Cambridge University Press. 
Turner, V. (1969). The ritual process: Structure and anti-structure. Ithaca, NY: Cornell University Press.

van der Beek, S. (2014). Pilgrim narratives in dialogue. In M. Farrelly \& V. Keely (Eds.), Pilgrim paths: Journeys of transformation (pp. 45-53). Oxford: Inter-Disciplinary Press.

van der Beek, S. (2017). Ritual identity. International Journal of Religious Tourism and Pilgrimage, 5(2), Art. 6. Retrieved from http://arrow.dit.ie/ijrtp/vol5/iss2/6

van Gennep, A. (1960). Rites of passage. Chicago, IL: University of Chicago Press.

Wicks, D. (1999). The information-seeking behavior of pastoral clergy: A study of the interaction of their work worlds and work roles. Library \& Information Science Research, 21(2), 205-26.

Nadia Caidi (nadia.caidi@utoronto.ca) is an Associate Professor at the Faculty of Information (iSchool), University of Toronto, Canada. Her research focuses on human information behavior, societal implications of information and communication technologies (ICTs), information policy, and cross-cultural studies. Dr. Caidi has received several grants for her research on information control and the public's right to know in times of crisis. Her current research is situated in the context of global migration and the role that information resources, institutions, and technologies play in the everyday lives of migrant and displaced communities. Caidi was President of the Canadian Association for Information Science (2011) and the 2016 President of the international Association for Information Science \& Technology (ASIS\&T). 